\title{
OPERATING CHARACTERISTICS OF THE A8C22 ENGINE IN AN SM42 LOCOMOTIVE FUELLED BY MIXTURES OF RME WITH DIESEL FUEL
}

\section{JERZY CISEK}

Cracow University of Technology, Krakow, Poland, E-mail: jcisek@pk.edu.pl

\section{ANDRZEJ MRUK}

Cracow University of Technology, Krakow, Poland, E-mail: mruk@mech.pk.edu.pl

\section{SHRNUTÍ}

Výzkum významnějši rozširǐení použití obnovitelných zdrojů (bio-paliv) ve spalovacích motorech trvá již vice než dvacet let. Jedním z výsledků je i směrnice EU, která nar̆izuje, že v cílovém roce 2020 by mělo být prídáváno až $20 \%$ biopaliv do ropných paliv. Ve střední Evropě, s ohledem na plodiny rostoucí v této klimatické zóně, je touto príměsí zejména řepkový olej a jeho metyl estery. Proto se výzkum týká těchto paliv.

Zkušebním motorem byl vidlicový osmiválec $s$ objemem jednoho válce $10,2 \mathrm{dm}^{3}$, typové značení $8 C 22$, největší výkon je $530 \mathrm{~kW}$ při jmenovitých otáčkách 1000 1/min. Tento motor je mimo jiné používán v posunovacích lokomotivách SM42. Po předchozích diagnostických průzkumech bylo použita čtyři paliva: standardní nafta (B0), to samé palivo se $40 \%$ príměsí (B40) a 50\% RME - metyl ester řepkového oleje (B50). Následně bylo zkoušeno palivo B50+ se speciálními aditivy. Výzkum energetických parametru a toxicity výfukových plynů byl prováděn na motoru zabudovaném do lokomotivy SM42. Zkoušky byly prováděny podle metodiky 2004/26/WE a UIC 624 Chart.

Bylo zjiššěno, že nárưst podílu RME (metylesteru řepkového oleje) až do hodnoty $50 \%$ v naftě, zvyšuje hodnotu hodinové spotřeby až o $10 \%$ prì volnoběhu a až o $15 \%$ při plném zatižení motoru oproti motorové naftě. Dále bylo zjištěno, že koncentrace $C 0$ ve výfukových plynech s rostoucí koncentrací esteru v palivu prii volnoběhu, při střední zátěži se nemění a naopak při plné zátěži motoru koncentrace CO klesají. Pro malou a střední zátěž byl vypozorován pokles $\mathrm{HC}$. Při volnoběhu bylo zjištěno snižení emisí $\mathrm{NO}_{x}$ prì nárưstu koncentrace RME. To je pro posunovací lokomitivy víznamné, protože často pracuji prì volnoběhu. Pro zkoušená paliva, byla stanoveny odolnost vưči karbonizaci vstrìkovačů a některé tribologické charakteristiky. Paliva obsahující do 40 \% RME vyhovují kritériu vzniku karbonizace.

KLIIČOVÁ SLOVA: VZNĚTOVÝ MOTOR, NÁHRADNÍ PALIVA, METYLESTER ŘEPKOVÉHO OLEJE, VÝFUKOVÉ PLYNY

\section{ABSTRACT}

Investigation into the wider use of renewable fuels (bio-fuels) in combustion engines has been carried out for over two decades. It has resulted in EU legislation that requires, by 2020 as the target date, the addition of $20 \%$ of bio-fuels to petroleum fuels. In Central Europe, with respect to the cultivation options in this climatic zone, these additives are mainly rapeseed oil and its methyl esters. Hence, the investigation has been focused on these fuels.

The examined $8 \mathrm{C} 22$ engine is a V8 engine of $10.2 \mathrm{dm}^{3}$ capacity per cylinder, with a power output of $530 \mathrm{~kW}$ at the rated speed of $1000 \mathrm{rpm}$. This engine is used, among others, in the SM42 shunting locomotives. After preliminary diagnostic research, 4 fuels were used: a standard diesel fuel (B0) and the same fuel with the addition of $40 \%$ (B40) and $50 \%$ of RME (B50). Additionally, the fuel B50+ with a pack of special additives was also examined. The investigation of the energy parameters and of the exhaust gases toxicity was performed on an engine fitted to the SM42 locomotive in the test house. The tests were performed in accordance with the 2004/26/WE Directive and UIC 624 Chart.

It was found that the increase of the RME part up to $50 \%$ in the mixture with diesel fuel increases the fuel consumption per hour by $10 \%$ when idling and by $15 \%$ when the engine is at full load, compared to the pure diesel fuel. It was also determined that the CO concentration in the exhaust gas increases as the concentration of the esters in the fuel was increased when idling; that there were no essential changes at intermediate working points; and that it decreases at full engine load. For medium and high engine loads, a reduction of $\mathrm{HC}$ was observed. When idling, a reduction of $\mathrm{NO}_{x}$ was observed as the ester concentration in the fuel was increased. It is essential for using the engine in shunting locomotives, because they often work without load. For the examined fuels, the resistances to injector coking as well as some selected tribology characteristics were determined. The fuels containing up to $40 \%$ of the RME satisfy the coking criterion.

KEYWORDS: DIESEL ENGINE, ALTERNATIVE FUELS, RAPESEED METHYL ESTER, EXHAUST GAS EMISSION 


\section{INTRODUCTION}

For more than two decades investigations have been carried out on the wider application of renewable fuels (bio-fuels) for combustion engines. It has resulted in EU legislation that requires, by 2020 as the target date, the addition of $20 \%$ of bio-fuels to petroleum fuels. In Central Europe, with respect to cultivation options in this climatic zone, these additives are mainly rapeseed oil and its methyl esters. Hence, the investigation is focused on these fuels.

Applying rapeseed oil in its natural form as a fuel for diesel engines involves a number of technical problems due to the differences in physical and chemical proprieties compared to diesel fuel. One of the methods for solving this problem is the transesterification of the vegetable oil by an alcoholysis with methanol or ethanol. As a result of this process, we obtain methyl or ethyl esters of rapeseed oil fatty acids with smaller molecules and with physical and chemical properties closer to the diesel fuel properties.

The application of bio-fuels as an alternative to diesel fuel is of interest mainly to users of large engines, using great amounts of fuel and having a large fleet of vehicles. Therefore, the research on applying the mixtures of diesel fuel with rapeseed oil methyl esters to supply the a8C22 combustion engine in an SM42 locomotive was undertaken. The results are presented in this paper. The examined engine was in a mediocre technical condition, the locomotive was admitted to the rail traffic.

\section{SCOPE AND METHODOLOGY OF RESEARCH}

The purpose of the investigation was to determine the influence of the examined bio-fuels (mixtures of rapeseed oil methyl esters) on the energy parameters and unitary emissions of the exhaust toxic components of an a8C22 engine in a SM42-2331 diesel locomotive, in accordance with Directive 2004/26/WE and the Charter UIC 624 and in comparison with the results obtained for the pure diesel fuel.

Four fuels were used to supply the a8C22 engine: standard diesel fuel $O N$, and the same with the addition of $40 \%$ and $50 \%$ fuel B100 - rapeseed oil methyl esters RME. Additionally, the fuel $B 50+$ with a pack of special additives was used. The fuels with a larger fraction of the B100 additive have been disqualified because of nozzle coking.

The investigation on energy parameters and emissions of the engine exhaust toxic components was carried out on a locomotive test stand. The loading of the engine-generator set was performed using an electric resistor ensuring the required working points of the engine.
The a8C22 combustion engine is a diesel four-stroke engine, with direct fuel injection. It is a V-type engine with a $50^{\circ}$ row angle, displacement of $81.6 \mathrm{dm}^{3}$, trunk-piston, non-reversible, turbocharged without intercooling. The basic technical data are presented in Table 1.

To measure gaseous components of exhaust gases $\left(\mathrm{CO}, \mathrm{HC}, \mathrm{NO}_{x}\right)$ limited by the standards, the AVL type CEB II exhaust gas analyzer was used. It included:

- infrared absorption detector NDIR measuring the concentration of carbon monoxide $\mathrm{CO}$,

- heated chemiluminescence detector CLD, measuring the concentration of nitric oxides $\mathrm{NO}_{x^{\prime}}$

- heated flame ionization detector FID, measuring the quantity of unburned [total] hydrocarbons $\mathrm{HC}$,

- magneto-optic detector PMD, measuring the concentration of oxygen $\mathrm{O}_{2}$,

- heated sampling path of exhaust gases with a heated preliminary filter,

- module determining the efficiency of $\mathrm{NO}_{2} / \mathrm{NO}$ conversion,

- divisor of the concentration of calibrating gases for determining linearization function for used detectors (16 linearizing gases were used with concentrations from 0 to maximum, i.e. the concentration of the calibrating gas).

\begin{tabular}{lc} 
Producer & $\begin{array}{c}\text { Metal Industry Factory } \\
\text { H. Cegielski - Poznań }\end{array}$ \\
\hline Type & a8C22 \\
\hline Number of cylinders & V8 \\
\hline Cylinder diameter & $220 \mathrm{~mm}$ \\
\hline Piston stroke & $270 \mathrm{~mm}$ \\
\hline Swept volume of 1 cylinder & $10.2 \mathrm{dm}^{3}$ \\
\hline Rated power & $530 \mathrm{~kW}$ \\
\hline Rated speed & $1000 \mathrm{rpm}$ \\
\hline Brake mean effective pressure Pe & $0.58 \mathrm{MPa}$ \\
\hline Compression ratio & 13.5 \\
\hline Compression pressure & $5.6 \mathrm{MPa}$ \\
\hline Maximum firing pressure & $10 \mathrm{MPa}$ \\
\hline Mean piston speed (at nominal speed) & $224 \pm 4 \mathrm{~m} / \mathrm{s}$ \\
\hline Minimum specific fuel consumption & $165 \pm 5 \mathrm{~g} / \mathrm{kWh}$ \\
\hline Injection pressure & $22 \mathrm{MPa}$ \\
\hline Firing sequence & $1-8-2-7-4-5-3-6$ \\
\hline Turbocharger & $\mathrm{HP} 210$
\end{tabular}

TABLE 1: Basic technical data for the a8C22 engine TABULKA 1: Základní technická data motoru 8C22

For measurement of smoke and particulates, the following equipment was used: Bosch (AVL) exhaust gas smoke meter, and the measuring system with a diluting tunnel for measuring particulate matter (PM) with a microbalance type Sartorius Photo 1, 2). 


\begin{tabular}{lccc} 
Test point & $\mathrm{n}[\mathrm{rpm}]$ & $\mathrm{Ne}[\mathrm{kW}]$ & $\mathrm{U}_{\mathrm{i}}[\%]$ \\
\hline $1 . \mathrm{n}_{\text {idle run }}$ & 500 & 0 & 60 \\
\hline $2 . \mathrm{n}_{\text {intermediate }}$ & 712 & 303 & 15 \\
\hline $3 . \mathrm{n}_{\text {nominal }}$ & 1000 & 530 & 25
\end{tabular}

TABLE 2: Measuring points for the a8C22 engine of the SM42 diesel locomotive used in the tests, in conformity with the points of the test $F$ according to Directive 2004/26/WE and weighting factors TABULKA 2: Body měření motoru 8C22 lokomotivy SM42 použité při testu, v souladu se měřicí body z metodiky 2004/26/WE a použití váhových faktorů

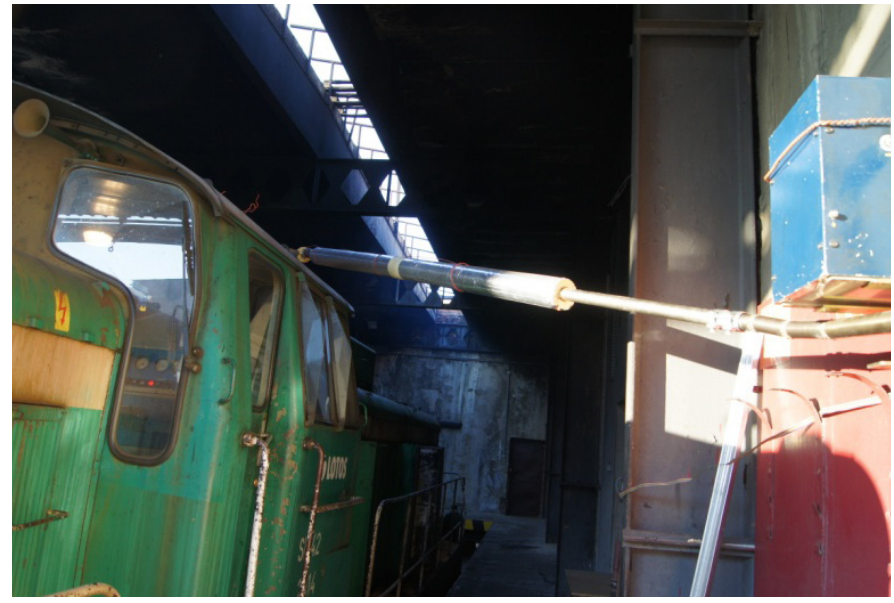

Рното 1: General view of the SM-42 locomotive, with the connection between the exhaust gas output and the detectors of exhaust gaseous components and exhaust gas smoke, and the tunnel diluting the exhaust gases (measurement of PM emissions)

1 - tested diesel locomotive, 2 - conduit delivering exhaust gas to detectors, 3 - heated inlet filter of exhaust gas analyzers.

FOTOGRAFIE 1:Pohled na lokomotivu SM-42 se spojením mezi výfukovým potrubím a čidly pro rozbor výfukových plynů a kouře a tunelem odlučovače (měření PM emisí)

1 - testovaná lokomotiva, 2 - spojnice vedoucí výfukové plyny do detektoru, 3 - vyhřivaný vstupní filtr analyzátorů výfukových plynů

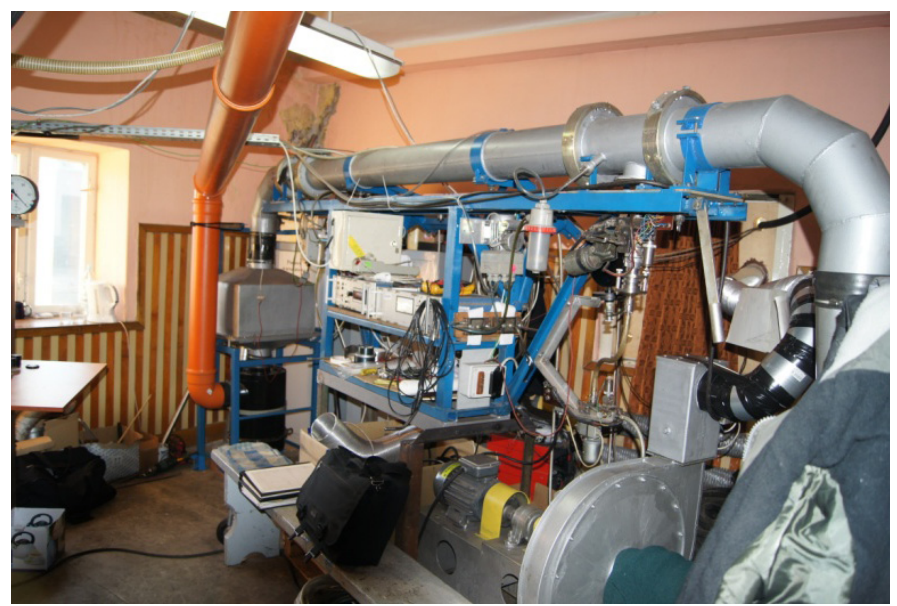

Рното 2: General view of the test stand for determining the particulate matter emissions with a tunnel diluting the exhaust gas.

FOTOGRAFIE 2: Celkový pohled na stanoviště pro určení emisí pevných částic s odlučovacím tunelem.

The base for calibration of the detectors used during the tests was reference gases with the degree of purity and accuracy of declared concentrations (required) according to the ECE standards.

The test stand fulfilled all requirements necessary to carry out the investigation determining the influence of the tested bio-fuels on energy parameters and on toxicity of the engine exhaust gases at operation points corresponding to the points of the test $F$ of Directive 2004/26/WE [1, 2], defined in Table 2.

A partial flow diluting tunnel was applied in testing, thus avoiding the necessity of maintaining the measurement isokinetic. To determine the dilution ratio (DR), according to the ECE R49 standards, the measurements of the CO concentration in raw exhaust gas, in diluted exhaust gas and in diluting air background were used. The gas humidity was of course taken into account.

\section{THE ANALYSIS OF TEST RESULTS}

\subsection{ENERGY PARAMETERS AND EXHAUST GAS TOXICITY}

During the performed testing, the values of energy parameters were measured as well as the concentrations of exhaust toxic components, for the examined fuels $(\mathrm{ON}, \mathrm{B} 40, \mathrm{~B} 50, \mathrm{~B} 50+)$ at working points of the engine operation in conformity with the test " $F$ " according to Directive 2004/26/WE. Each measuring point was repeated three times. Test results are presented in the diagrams (Figure $1-5$ ). In the diagrams, successive points of the test $F$ are denoted 1,2 , and 3 .

The basic energy parameter, essential from the point of view of the exploitation of the combustion engine driving the tested SM42 shunting locomotive, is fuel mass flow rate expressed in kilograms of fuel consumed per hour of the engine operation. The results of investigation of this parameter for idling, intermediate power/speed and for the rated power/speed (Table 2) are presented in Figure 3 . The results of analysis show that the increase of the rapeseed oil methyl esters part up to $50 \%$ RME in diesel fuel leads to an increase of the fuel mass flow rate by about $10 \%$ at idle running and by about $15 \%$ at a nominal point of engine operation. However, it must be remembered that the diesel fuel and RME have different calorific values and fuel densities. Then, neither the mass flow rate nor brake specific fuel consumption can be representative parameters in the assessment of the tested fuel quality.

The only parameter that fully reflects energy features of the tested fuels is brake efficiency $\eta_{0^{\prime}}$ which takes into account both the specific fuel consumption and the fuel calorific value. The percentage difference in the calorific values of diesel

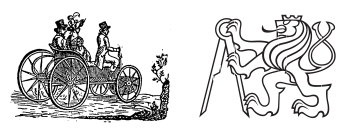

Operating Characteristics of the a8C22 Engine in an SM42 Locomotive Fuelled 


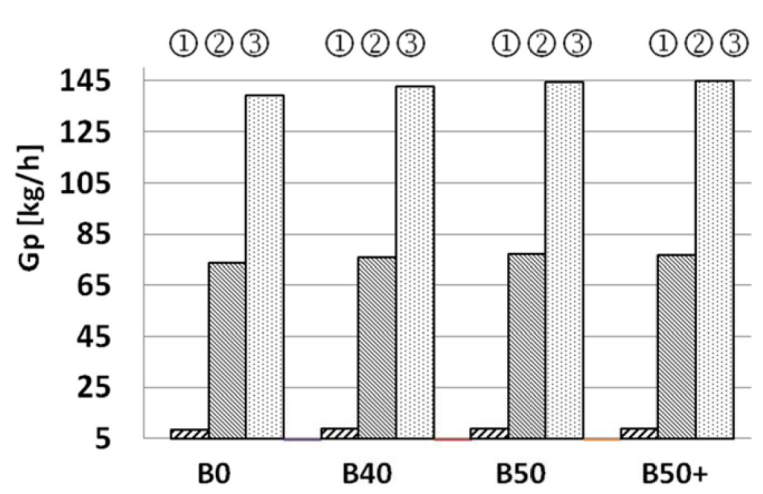

FIGURE 1: Fuel mass flow rate for the tested fuels OBRÁZEK 1: Hmotnostní průtok testovaných paliv

fuel and B50 fuel is only about 4\%, and the hourly and the specific fuel consumptions differ by as much as $15 \%$ at full engine load. This results from the fact that the general engine efficiency for the fuel B50 is lower than for the diesel fuel. This is due to the deterioration of injection processes, to the creation of the fuel-air mixture, to the self-ignition and the combustion itself as well as to the elementary composition of the tested bio-fuel in comparison with the diesel fuel.

Because of the different values for the physical and chemical parameters of diesel fuel and RME, the injection, spraying, mixing the fuel with the air and the combustion processes are different for these fuels. As a result, due to the cause and effect phenomena described in detail, for instance in [6], a negative effect of the addition of rapeseed oil methyl esters to a conventional fuel on the toxic exhaust gas components is observed. The essence of this problem is not only the different chemical composition of the analyzed fuels, but also a significant deterioration of the RME spraying quality and uniformity as compared to the diesel fuel [7].

Carbon monoxide (CO) is a typical product of incomplete combustion. This compound arises at a local oxygen deficiency

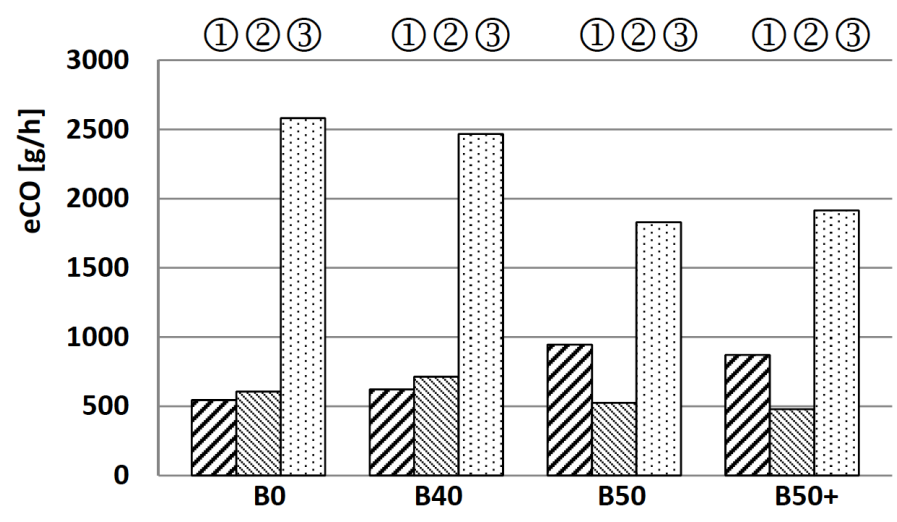

FIGURE 2: Hourly emission Eco of carbon monoxide for the tested fuels OBRÁZEK 2: Hodinové emise CO pro testovaná paliva

in the combustion chamber. The test results (Figure 2) show clearly that increasing the RME content in the tested fuel causes:

- increase of $\mathrm{CO}$ concentration for idling,

- lack of significant changes in CO concentration for intermediate point of the engine operation,

- decrease of CO concentration for the engine full load.

$\mathrm{CO}$ concentrations in the engine exhaust gas when comparing the effect of using bio fuels or diesel fuel are both affected by the factors positively influencing the processes of preparing the fuel-air mixture and the combustion process, and the factors acting negatively on these processes.

The change of the equilibrium between these phenomena means that at low engine loads, the effect of the bio fuel amount in diesel fuel has a different influence than in the case of high engine load.

The results of the investigation of total hydrocarbons ( $\mathrm{HC}$ ) concentration in exhaust gas for the fuels ON (BO), B40, B50, $\mathrm{B} 50+$ for idle running, for intermediate speed and for nominal point of the engine operation, are presented in Figure 3.

The analysis of the results shows that the influence of the tested fuels on the concentration of unburned total hydrocarbons is

\begin{tabular}{|c|c|c|c|c|c|c|}
\hline \multirow[t]{2}{*}{$\begin{array}{l}\text { Exhaust gas } \\
\text { components }\end{array}$} & \multicolumn{2}{|c|}{$\begin{array}{c}\text { Limits from 01.01.2003 } \\
{[\mathrm{g} / \mathrm{kWh}] \text { UIC II }}\end{array}$} & \multirow{2}{*}{$\begin{array}{l}\text { Limits from } 01.01 .2006 \\
\text { [g/kWh] UIC III A } \\
\mathrm{P}<130 \mathrm{~kW}\end{array}$} & \multirow{2}{*}{$\begin{array}{c}\text { Limits from } 01.01 .2007 \\
\text { [g/kWh] UIC III A } \\
P>130 \mathrm{~kW} \\
P \leq 560 \mathrm{~kW}\end{array}$} & \multirow{2}{*}{$\begin{array}{c}\text { Limits from 01.01.2009 } \\
\text { [g/kWh] UIC III A } \\
\text { P } \leq 560 \mathrm{~kW}\end{array}$} & \multirow{2}{*}{$\begin{array}{c}\text { Limits from 01.01.2009 } \\
\text { [g/kWh] UIC III A } \\
\text { P>2000 kW i }\end{array}$} \\
\hline & $P \leq 560 k W$ & $P>560 \mathrm{~kW}$ & & & & \\
\hline $\mathrm{CO}$ & 2.5 & 3 & 3.5 & 3.5 & 3.5 & 3.5 \\
\hline \multirow[t]{2}{*}{$\mathrm{NO}_{\mathrm{x}}$} & 6 & $\begin{array}{c}\mathrm{n}>1000 \mathrm{rpm} \\
9.5\end{array}$ & $\begin{array}{c}\mathrm{NO}_{\mathrm{x}}+\mathrm{HC} \\
4.0\end{array}$ & $\begin{array}{c}\mathrm{NO}_{\mathrm{x}}+\mathrm{HC} \\
4.0\end{array}$ & 6.0 & 7.4 \\
\hline & & $\begin{array}{c}\mathrm{n} \leq 1000 \mathrm{rpm} \\
9.9\end{array}$ & & & & \\
\hline $\mathrm{HC}$ & 0.6 & 0.8 & & & 0.5 & 0.4 \\
\hline PM & 0.25 & 0.25 & 0.2 & 0.2 & 0.2 & 0.2 \\
\hline Test & $\mathrm{F}$ & $\mathrm{F}$ & C.1 & $\mathrm{F}$ & $\mathrm{F}$ & $\mathrm{F}$ \\
\hline
\end{tabular}

TABLE 3: Limits for the exhaust gas toxic components according to UIC 624

TABULKA 3: Limity toxických látek ve výfukových plynech podle směrnice UIC 624 


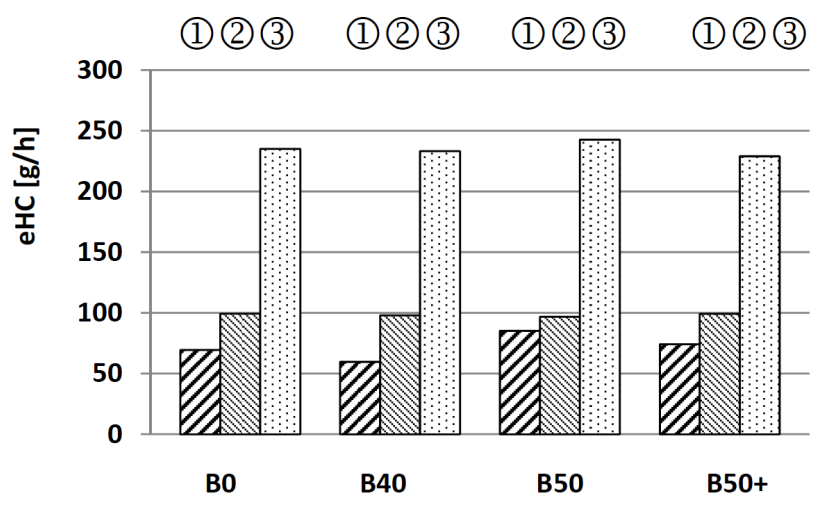

FIGURE 3: Hourly emissions of unburned [total] hydrocarbons OBRÁZEK 3: Hodinové emise nespálených uhlovodíků HC

insignificant. However, the influence of the bio-fuels addition (to B50) on the increase of $\mathrm{HC}$ concentration at idle running is noticeable. Idling takes place at low fuel charges, which is well known to lead to a considerable non-repeatability of the fuel dosage, especially in the case of changing the characteristics of physical and chemical parameters of the used fuels. This may be the cause of the increase of $\mathrm{HC}$ concentration at idle running. At the other points of the engine operation (intermediate speed and nominal point of the engine operation), the $\mathrm{HC}$ concentrations remain at a similar level.

The next parameter of exhaust gas toxicity tested and analyzed was the concentration of nitrogen oxides $\left(\mathrm{NO}_{\mathrm{x}}\right)$. The results are presented in Figure 4. As with the $\mathrm{CO}$ concentration and total hydrocarbons $\mathrm{HC}$, for the concentration of nitrogen oxides $\mathrm{NO}_{x}$, the greatest effect of the tested bio-fuels occurs at engine idling. This is very important, because shunting locomotives of this kind idle very frequently. For the same reason, the weight fraction in " $F$ " test for the idle run has the highest value $(60 \%)$. It is clear that an increase of the RME part in diesel fuel involves a decrease in the $\mathrm{NO}_{x}$ concentration in the engine exhaust gas. However, at higher engine loads, the addition of RME to diesel

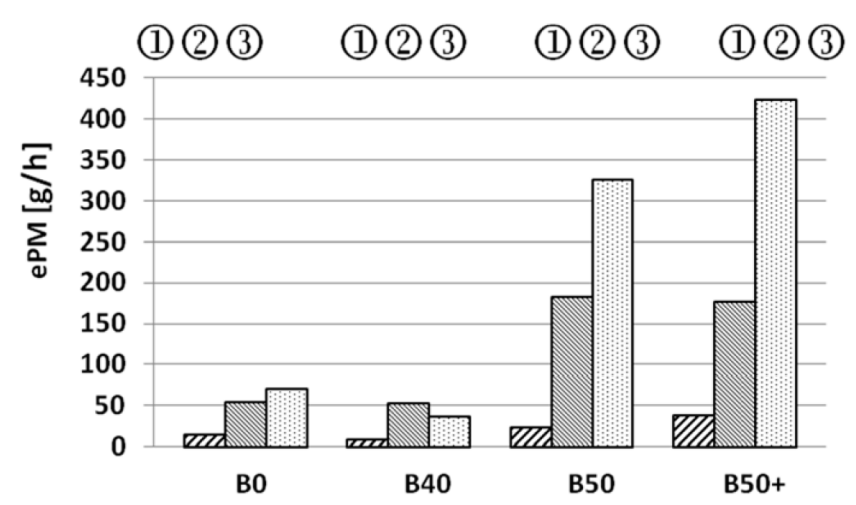

FIGURE 5: Hourly emissions of particulate matter (PM) for the tested fuels OBRÁZEK 5: Hodinové emise pevných částic zkoušených paliv

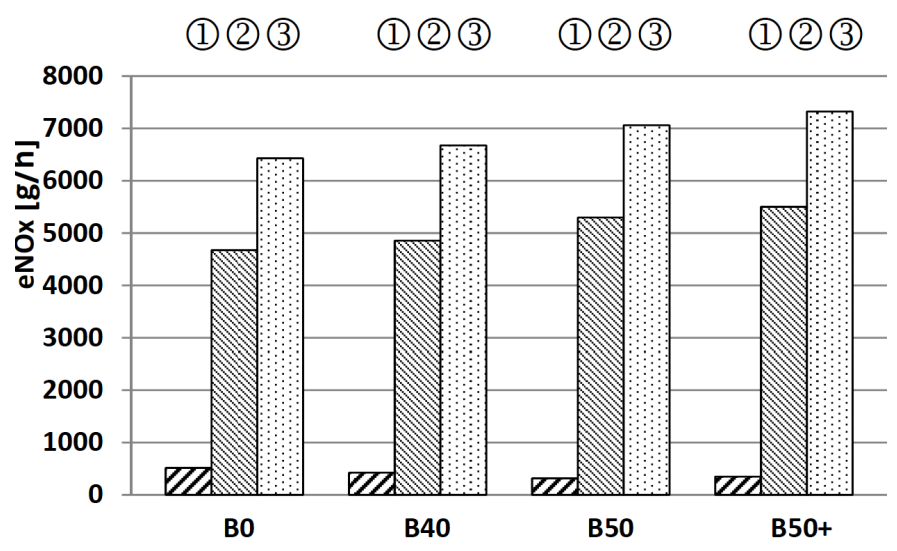

FIGURE 4: Hourly emissions of nitric oxides OBRÁZEK 4: Hodinové emise oxidů dusíku.

fuel causes an increase in the $\mathrm{NO}_{x}$ concentration. Extremely important is the fact that the pack of special additives to the fuel (B50+) caused a significant decrease in the concentration, but also a small decrease in the emissions of incomplete and deficient combustion compounds ( $\mathrm{CO}, \mathrm{HC}$ - for idle running). As the decrease in the amount of Nitric oxides $\mathrm{NO}_{x}$ in the engine exhaust gas, due to the increase of RME in diesel fuel, is significantly higher than the decrease in $\mathrm{HC}$ and $\mathrm{CO}$ emissions, it is to be expected that the used additive would cause a shortening of the ignition time $\operatorname{lag} \tau_{s}$. The shortening $\tau_{s}$ reduces the time between the fuel injection start and the ignition start. This results in decreasing the fuel charge, which accumulates in the engine combustion chamber before the ignition. Because of this, the fuel ignition is less dynamic, the maximum speed of pressure increase has a lower value and as a consequence the maximum temperatures of ignition are lower, and thus the $\mathrm{NO}_{x}$ concentration is lower too.

The results of the investigation of the exhaust gas smokiness $D$ show that the RME addition to the diesel fuel has an influence on the exhaust gas smokiness. For all tested fuels, the increase in the RME part involves increasing the degree of the exhaust gas smokiness measured using the Bosch method.

The exhaust gas smokiness, like the emissions of PM, is connected largely to thermal and/or chemical cracking of the fuel, involving an increase of the soot amount in the exhaust gas. The difference between the emission of particulates and the exhaust gas smokiness lies in the fact that the exhaust smokiness involves only the exhaust gas blackout, while the emission of particulates $E_{P M}$ concerns the whole organic and inorganic matter accumulated on the outer surface of the soot conglomerates formed by the most toxic compounds contained in the exhaust gas.

That is why the regulations legally binding now, concerning automotive vehicles as well as stationary engines and combustion locomotives, have ceased to rely on measuring only 


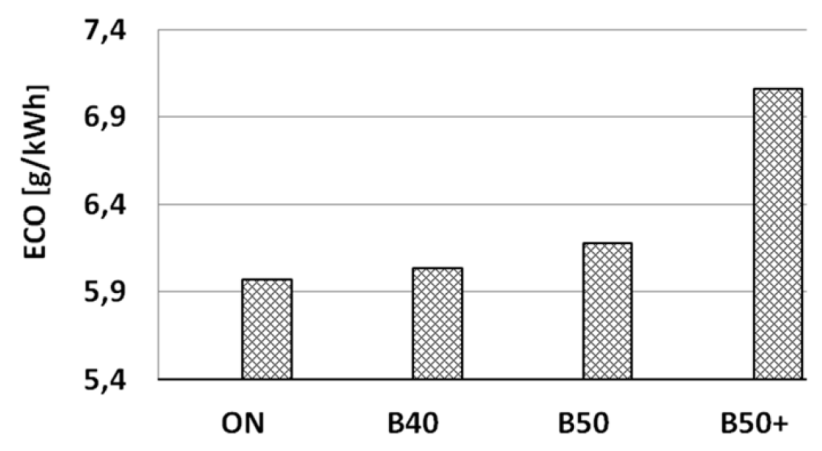

FIGURE 6: Specific emissions of carbon oxide $\mathrm{CO}$ in the $\mathrm{F}$ test according to Directive 2004/26/WE for the tested fuels

OBRÁZEK 6: Měrné emise CO v testu F podle směrnice 2004/26/WE pro zkoušená paliva

the exhaust gas smokiness, and they now include the emission of particulate matter $\mathrm{E}_{\mathrm{PM}}$.

\subsection{EMISSION OF THE EXHAUST GAS TOXIC COMPONENTS ACCORDING TO UIC 624}

The limits for permissible emissions of the exhaust gas toxic components according to UIC 624 are presented in Table 3.

The results of the investigation on unitary emission of the exhaust gas toxic components, performed in accordance with UIC 624 Charter, are presented graphically in Figure 6-9.

The analysis of the obtained results shows that the brake specific emission of the carbon oxide $\left(\mathrm{E}_{\mathrm{CO}}\right)$ - Figure 6 - significantly exceeds the limit values determined by UIC 624 standards (Table 3). This relates both to the diesel fuel and all tested bio fuels. The boundary value for the $E_{c 0}$ emissions, determined by Directive 2004/26/WE and the Charter UIC 624, is $3.5 \mathrm{~g} / \mathrm{kWh}$.

The increase of the RME amount in the mixture with diesel fuel $(\mathrm{ON})$ caused an increase in $\mathrm{CO}$ emissions in the exhaust gas. For the fuel $B 50$, the emission $E_{c 0}$ was $6.18 \mathrm{~g} / \mathrm{kWh}$, while for $B 50+$ the emission $E_{c o}$ increased to the value $7.06 \mathrm{~g} / \mathrm{kWh}$. Though the applied set of additives to the fuel B50 caused an

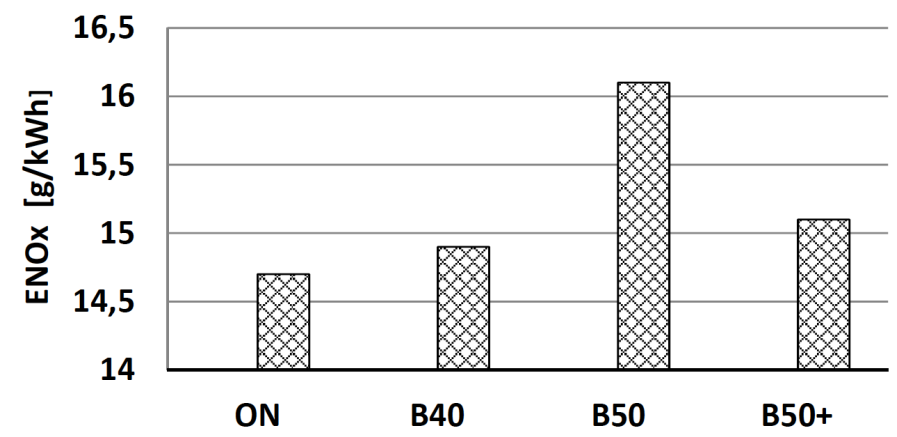

FIGURE 8: Unitary emissions of nitrogen oxides $\mathrm{NO}_{\mathrm{X}}$ in the $\mathrm{F}$ test according to Directive 2004/26/WE for the tested fuels OBRÁZEK 8: Jednotkové emise $\mathrm{NO}_{x}$ v testu F podle směrnice 2004/2006/ WE pro zkoušená paliva

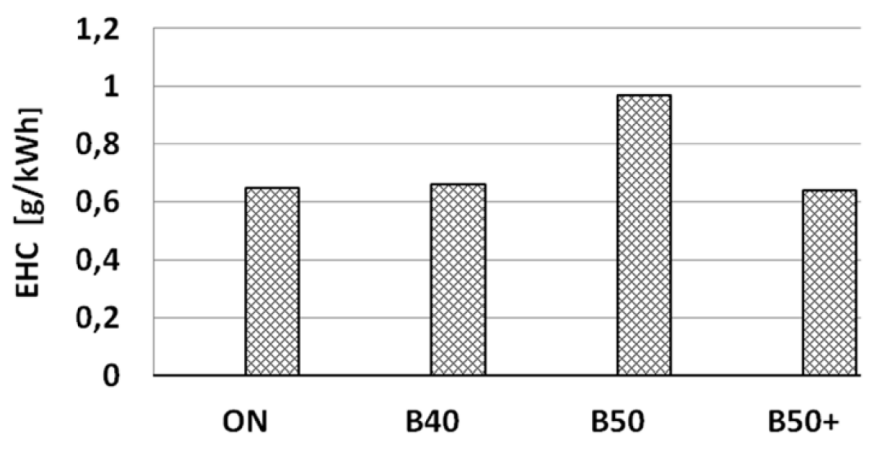

FIGURE 7: Unitary emissions of unburned hydrocarbons $\mathrm{HC}$ in the $\mathrm{F}$ test of Directive 2004/26/WE for the tested fuels

OBRÁZEK 7: Jednotkové emise nespálených uhlovodíků HC v testu F podle směrnice 2004/2006/WE pro zkoušená paliva

increase of incomplete combustion compounds (CO) in this fuel, it contributed at the same time to a decrease in the amount of nitrogen oxides $\mathrm{NO}_{x}$.

The data presented in Figure 8 confirm that a special addition to the fuel $\mathrm{B} 50+$ decreases the ignition delay time $\tau_{s}$ and maximum combustion temperature causing a decrease of emissions of nitric oxides $\left(\mathrm{E}_{\mathrm{NO}}\right)$, compared to the fuel $\mathrm{B} 50$. This is important because it is well known that the emission of nitric oxides $\mathrm{E}_{\mathrm{NO}}$ is the most harmful (of the exhaust gaseous components) for living organisms. By reducing the self-ignition delay in the diesel engine, the proportion of the fuel dose injected into the combustion chamber before the self-ignition decreases. This results in a lowering of the combustion dynamics and the maximum combustion temperature, and as a consequence, leads to a reduction in the emission of nitric oxide $\mathrm{NO}_{x}$ in exhaust gas. A similar effect of the bio fuels contents was observed for the specific emission of unburned hydrocarbons $\mathrm{E}_{\mathrm{HC}^{\prime}}$ which is presented in Figure 7. Increasing the RME content up to $50 \%$ in diesel fuel (ON) causes an increase in the amount of unburned hydrocarbons. With the additive pack in the fuel $\mathrm{B} 50(\mathrm{~B} 50+)$ we

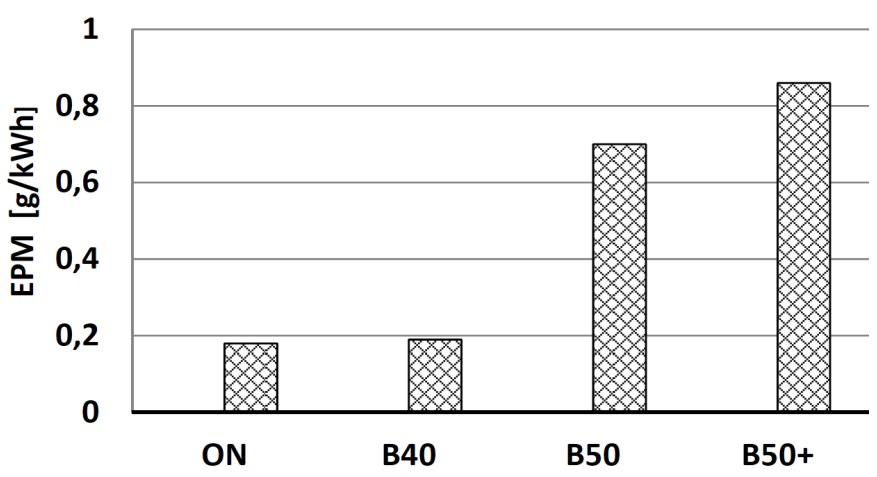

FIGURE 9: Unitary emissions of particulate matter in the F test according to Directive 2004/26/WE for the tested fuels

OBRÁZEK 9: Jednotkové emise pevných částic v testu F podle směrnice 2004/2006/WE pro zkoušená paliva 
saw a reduction in the unitary emission $\mathrm{E}_{\mathrm{HC}}$ after the test " $\mathrm{F}$ " of about $34 \%$.

The values of the brake specific emission of particulate matter $E_{P M}$ are presented in Figure 9. The fuel B40 has similar values of $E_{P M}$ to the diesel fuel. Further increase of the amount of RME in ON results in rapidly increasing emissions of particulate matter $E_{P M}$ in the tested a8C22 engine of the SM42 diesel locomotive. This is important because particulate matter is, apart from nitric oxides $\mathrm{NO}_{x}$, the most carcinogenic and mutagenic of all the toxic components of diesel engine exhaust gases.

\section{CONCLUSIONS}

The performed investigation leads us to formulate the following essential conclusions:

The increase of the proportion of rapeseed oil methyl esters (RME) up to a content of $50 \%(\mathrm{~m} / \mathrm{m})$ in the mixture with diesel fuel causes an increase in the value of the hourly fuel consumption by about $10 \%$ at idle running and by about $15 \%$ at full engine load when compared to the diesel fuel.

Increasing the amount of RME in diesel fuel involves a slight decrease in the value of the combustion engine brake efficiency. The influence of the tested bio fuels on the concentrations of the exhaust gaseous components, as compared to the diesel fuel, is connected with the engine load. An increase in $\mathrm{CO}$ concentration in the exhaust gas is associated with the amount of RME when idling, there are no significant changes in $\mathrm{CO}$ concentration at the intermediate operation point, and there is a slight decrease at full load. The concentration of the carbon oxide $E_{c 0}$ after the test " $F$ " significantly exceeds the boundary values determined by the UIC 624 standard. This relates to both the diesel fuel and all tested fuel mixtures. Increasing the amount of RME in the mixture with diesel fuel $(\mathrm{ON})$ caused an increase in the unitary emission $E_{c 0}$ after the test " $F$ ".

At intermediate and high engine loads, a positive effect of adding RME to diesel fuel in reducing the concentration of unburned hydrocarbons $\mathrm{HC}$ was determined.

For the fuel B40, the emission of particulate matter $E_{P M}$ does not differ significantly from the emissions for diesel fuel. However, a further increase in RME content in the mixture with $\mathrm{ON}$ causes a rapid increase of $E_{P M}$ for the tested a8C22 engine.

The concentration of nitrogen oxides $\mathrm{NO}_{\mathrm{x}}$ decreases as the amount of bio fuels in the mixture with ON decreases when idling. This is significant because diesel engines in locomotives of this kind typically work for long periods without being loaded, which is expressed by the highest value of the weight fraction in the test " $F$ " for this point of the engine operation.

\section{REFERENCES}

[1] Directive 2004/26/WE

[2] International Union of Railways. UIC 624 Railway Code. Research on exhaust gas emissions of traction combustion engines. Edition 3, February 2006.

[3] Cisek J. (2009). Research on the influence of natural rape oil on the characteristics of diesel engine Perkins 2806A-E18TAG2 (Badania wpływu naturalnego oleju rzepakowego na własności silnika wysokoprężnego Perkins 2806A-E18TAG2) - Test report for PPUH HORUS-ENERGIA Ltd. Vol. 556/IPSiSS/2009. Cracow University of Technology, Cracow.

[4] Cisek J. (2010). Research on a new type of fuel for a diesel engine (Badania paliwa nowego typu do silnika ZS) Test report for ECOLOGICAL TECHNOLOGIES, Vol. 557/ IPSiSS/2009. Cracow University of Technology, Cracow.

[5] Cisek J. (2011). Measurement of nozzle coking for bio fuels B100, B70, B50, B40, B30 compared with diesel fuel ON and research on the influence of three bio fuels compared with diesel fuel on the operation parameters of the engine a8C22 in the combustion locomotive SM42-2331, in accordance with the Directive 2004/26/WE and the Charter UIC 624 (Pomiar zakoksowania rozpylaczy paliwa dla biopaliw B100, B70, B50, B40, B30 w porównaniu z olejem napędowym $\mathrm{ON}$ oraz badania wpływu 3 biopaliw w porównaniu z olejem napędowym ON na parametry pracy silnika a8C22 lokomotywy spalinowej SM42-2331, zgodnie z Dyrektywą 2004/26/WE oraz Kartą UIC 624) - Test report for LOTOS Poland PLC. Cracow University of Technology, Cracow.

[6] Cisek J., Mruk A. (2010). Naturalny olej rzepakowy jako paliwo do silników wysokoprężnych dużej mocy (Natural rape oil as the fuel for high-power diesel engines). Systems, Technologies and Energy Installations. Vol. 1, chap. 3, pp. 377-392. Editions of Cracow University of Technology, Cracow. ISBN 978/83/724-543-0.

[7] Cisek J. (2012). Optical research on the fuel injection into a diesel engine for diesel fuel, RME and rape oil. Journal of KONES. European Science Society and Transport Publication. Warsow, Vol. 19, No. 3. pp. 65-74. Permanent Comitete of KONES. ISSN 1231-4005 